\title{
MANAJEMEN PRODUKSI RUMPUT LAUT GRACILARIA (Gracilaria sp) DI DESA DOMAS, PONTANG, SERANG-BANTEN
}

\author{
Ramarsa Hidayatulbaroroh \\ Jurusan Teknologi Pengelolaan Sumberdaya Perairan, \\ Sekolah Tinggi Perikanan, Jakarta. \\ Email: ramarsa.hidayat@gmail.com
}

\begin{abstract}
Abstrak - Gracilaria merupakan komoditas yang memiliki permintaan tinggi. Tujuan dari praktik akhir ini adalah mengetahui dan memahami budidaya rumput laut Gracilaria sp. Praktik akhir dilaksanakan dari 6 Februari-6 Mei 2017 di Desa Domas, Pontang, Serang, Banten. Aspek yang diamati dan dipelajari adalah aspek manajemen, teknis dan finansial. Data dikumpulkan melalui mengikuti kegiatan petambak dan melakukan pengumpulan data secara mandiri. Cara memperoleh data melalui wawancara petani, melakukan dan mengamati, serta melakukan kegiatan mandiri tergantung dengan parameter yang diamati. Kawasan budidaya Gracilaria di Domas secara spesifik berada di lokasi Crocoh, Kali Domas dan Teluk. Tambak berjumlah 33 dengan keseluruhan sistem budidaya polikultur gracilaria dengan bandeng. Laju pertumbuhan gracilaria rata- rata pada kawasan Crocoh dan Kali Domas yaitu 1,95\% dan 1,53\%. Tambak sampel kawasan Teluk memiliki laju pertumbuhan gracilaria 3\%; 2,1\% dan -32\%. Pemekaran mempengaruhi hasil pertumbuhan. Hasil pengukuran bobot akhir perlakuan pemekaran setiap 2 minggu, pemekaran setiap 3 minggu dan tanpa pemekaran berturut-turut menjadi 9 kali lipat, 8 kali lipat dan 5 kali lipat dari bobot awal. Hasil pengukuran parameter kualitas air yaitu suhu $29-39^{\circ} \mathrm{C}$, salinitas $0-31 \mathrm{~g} / \mathrm{l}, \mathrm{pH} 6-8$, nitrat 0-50 mg/l, fosfat 0,1-2 mg/l dan kalium 200-420 mg/l. Sebagian besar tambak memiliki penetrasi cahaya hingga dasar dengan ketinggian air 9-50 cm. Rata-rata pengisian air hanya 4 jam per hari pada malam hari dan pengeluaran air 3 jam per hari pada dini hari. Hama dan penyakit yang ditemukan selama praktik adalah Hypnea muscoformis, Achanthopora, Chaetomorpha, Lingbya, Siganus sp., Lates calcalifer, Sillago sihama dan ice- ice. Budidaya polikltur Gracilaria dan bandeng menguntungkan karena memiliki rata-rata investasi Rp 3.900.350,-; biaya tetap $R p$ 17.468.739,-; biaya tidak tetap $R p$ 45.632.919,-; laba $R p$ 34.100.258,-; dengan empat tambak mengalami kerugian, $B / C$ ratio 1,65 , BEP unit $16.828 \mathrm{~kg}$ dengan nilai rupiah Rp 94.235.182,-; PP 55 tahun 6 bulan dan ROI 5,3\%.
\end{abstract}

Kata kunci : Gracilaria, budidaya, manajemen, Serang

\begin{abstract}
Gracilaria is one of valuable and demanding aquaculture commodities in Indonesia. The purpose of the study was to know and understand the cultivation of seaweed Gracilaria sp. The study was done from 6 February 2017 until 6 May 2017 in Domas Village, Pontang, Serang, Banten. Data on management, technical, and financial were collected by attending seaweed farmer's culture activities and interviewing them. Observed site was specifically located at Crocoh, Kali Domas and Teluk. There were 33 ponds of polyculture between Gracilaria and milkfish. The average growth rate of seaweed cultured by farmer in Crocoh and Kali Domas were 1,95\% and 1,53\%, respectively. Meanwhile in Teluk region had growth rate of $3 \% ; 2,1 \%$ and $-32 \%$. Result of final biomass relative to first sown seed biomass (100 gram) of treatment of spreading every 2 weeks, 3 weeks, and control (without spreading) were 9 fold, 8 fold, and 5 fold. The result of measurement of several water quality parameter were temperature $29-39^{\circ} \mathrm{C}$, salinity $0-31 \mathrm{~g} / \mathrm{l}, \mathrm{pH}$ 6-8, nitrate $0-50 \mathrm{mg} / \mathrm{l}$, phosphate $0,1-2 \mathrm{mg} / \mathrm{l}$, and potassium 200-420 mg/l. Most of the ponds had light penetration until buttom of the pond with the depth of the water about 9-50 $\mathrm{cm}$. Daily duration to add water was 4 hours at night and 3 hours in early morning to throw water. Pests and diseases found during study were Hypnea muscoformis, Achanthopora, Chaetomorpha, Lingbya, Siganus sp., Lates calcalifer, Sillago sihama, and ice-ice. The polyculture between Gracilaria and milkfish was feasible to be continuesly developed because it had average of investment Rp 3,900,350,-; fixed cost Rp17,468,739,-; variable cost Rp45,632,919,-; profit Rp34,100,258,- with four ponds suffered losses, B/C ratio 1.65; BEP (unit) 16,828 kg, BEP (price) Rp94,235,182,-; PP 55 years 6 months and ROI $5.3 \%$..
\end{abstract}

Keywords: Gracilaria, cultivation, management, Serang 


\section{PENDAHULUAN}

Budidaya rumput laut gracilaria (Gracilaria sp.) di Indonesia memiliki potensi lahan yang luas. Potensi lahan tambak seluas 2.964.331 ha dengan pemanfaatan 667.083 ha $(22,5 \%)$ sehingga terdapat peluang pengembangan hingga 2.297.248 ha (Rahmantya dkk., 2015b). Selain itu, dapat menggunakan tambak untuk udang dan ikan yang sudah tidak berproduksi (Indriani dan Sumiarsih, 2005).

Menurut Anggadiredja $d k k$. (2006) rumput laut gracilaria secara taksonomi dapat diklasifikasikan sebagai Divisi Rhodophyta, Kelas Rhodophyceae, Bangsa Gigartinales, Suku Gracilariaceae, Marga Gracilaria. Gracilaria termasuk dalam rumput laut merah. Thallus alga merah memiliki bentuk, tekstur, dan warna yang beragam. Selain itu, rumpun juga memiliki bentuk dari filament hingga kompleks (Prabowo dan Farchan, 2008). Untuk thallus gracilaria umumnya berbentuk silindris atau menipis dengan ujung meruncing (Sjafrie, 1990). Gracilaria tergolong tanaman berderajat rendah. Tanaman ini tidak mempunyai akar, batang maupun daun sejati, tetapi hanya menyerupai batang yang disebut thallus (Sunaryat $d k k$., 2008). Untuk melekatkan dirinya, gracilaria memiliki suatu alat cengkeram berbentuk cakram yang dikenal dengan sebutan holdfast (Sjafrie, 1990).

Rumput laut banyak mengandung mineral penting untuk kesehatan tubuh. Mengandung karbohidrat (gula atau vegetable gum), protein, sedikit lemak, abu, kalium dan vitamin (A, B1, B2, B6, B12, C, dan betakaroten) (Anggadiredja dkk.,2006). Gracilaria mengandung agar yang bisa dimanfaatkan dibanyak bidang. Agar terbentuk dari campuran dua polisakarida yaitu agarosa dan agaropektin (Philip dan Peter, 2000 dalam Nasuha dkk., 2014). Fungsi utama agar-agar adalah sebagai bahan pemantap, bahan pembuat emulsi, bahan pengental, bahan pengisi dan bahan pembuat gel. Industri yang membutuhkan agar meliputi industri makanan, farmasi, kosmetik, tekstil, kulit, dan lain-lain (Indriani dan Sumiarsih, 2005). Gracilaria memiliki manfaat lain selain menjadi sumber agar. Gracilaria mengandung senyawa anti bakteri yang potensial untuk menghambat dan membatasi pertumbuhan bakteri dan sebagai biofilter dalam usaha budidaya polikultur (Rahmaningsih, 2012). Selain itu, mampu mengurangi pencemaran perairan yang mengandung bahan beracun
(Yulianto dkk., 2006). Oleh karena itu,gracilaria dapat menjadi solusi ekonomis untuk mengurangi pencemaran karena mampu mengurangi nitrogen pada perairan (Jagadeesan dkk., 2010).

Nilai produksi yang tinggi membutuhkan pemenuhan dari budidaya agar suplai berkelanjutan. Nilai produksi gracilaria tahun 2010-2014 berturut-turut $22.474,60$ ton; $18.337,00$ ton; $77.616,61$ ton; $98.475,62$ ton dan $57.454,00$ ton (Rahmantya $d k k ., 2015 b)$. Volume kontribusi ekspor pada 2010 berada pada kisaran 10\% hingga menjadi kisaran 20\% pada 2015 (Rahmantya dkk., 2015a). Namun, pengambilan rumput laut dari alam dalam jumlah besar dapat mengganggu keseimbangan komunitas hewan dan tumbuhan di lokasi serta mempercepat erosi pantai. Oleh karena itu, dibutuhkan pemenuhan rumput laut dari hasil budidaya karena lebih sederhana dan lebih efisien (Parker, 2012).

Budidaya gracilaria mengalami masalah dibeberapa lokasi yang meliputi masalah teknik dan non teknik. Masalah teknik seperti kualitas bibit yang rendah, serangan hama, hasil produksi yang rendah (Wahab, 2016), serta penanganan pasca panen yang kurang tepat (Jamal, 2016). Sedangkan, masalah non teknik berupa masalah legalitas usaha, belum adanya kelompok pembudidaya (Wahab,2016) dan biaya pemasaran yang tinggi karena tersebarnya lokasi produsen yang jauh dari konsumen (Jamal, 2016)

Kawasan budidaya yang masih aktif berproduksi salah satunya berada di kawasan Desa Domas Kecamatan Pontang Kabupaten Serang Provinsi Banten. Desa Domas adalah kawasan minapolitan di Kabupaten Serang. Berdasarkan data statistik perikanan 2016 DKP Kabupaten Serang, hasil produksi kawasan ini mencapai 6.600 ton. Salah satu kelompok yang mengelola kawasan ini adalah P2MKP Maju Bersama. Oleh karena itu, penulis mengambil judul Manajemen Produksi Rumput Laut Gracilaria (Gracilaria sp.) di Domas Pontang Serang Banten. Berdasarkan hal tersebut adapun tujuan dari penelitian ini adalah (1) Mengetahui dan memahami aspek manajemen budidaya Gracilaria sp. Di Desa Domas, (2) Mengetahui dan memahami aspek teknik budidaya Gracilaria sp. di Desa Domas (3) Mengetahui dan mamahami aspek finansial budidaya Gracilaria sp. Di Desa Domas. 


\section{METODE PENELITIAN}

Metode yang digunakan dalam penelitian ini adalah metode praktek eksperimetal. Penelitian dilakukan di Desa Domas, Kecamatan Pontang, Kabupaten
Serang, Provinsi Banten. Adapun bahan yang digunakan untuk keperluan pengambilan data. dapat dilihat pada Tabel 1.

Tabel 1. Bahan praktik

\begin{tabular}{|c|l|l|l|l|}
\hline No & $\begin{array}{r}\text { Nama } \\
\text { bahan }\end{array}$ & \multicolumn{1}{|c|}{ Spesifikasi } & Jumlah & \multicolumn{1}{|c|}{ Fungsi } \\
\hline 1 & pH paper & Ketelitian 1 & 1 buah & Mengukur pH air \\
\hline 2 & $\begin{array}{l}\text { Nitrat test } \\
\text { kit }\end{array}$ & $\begin{array}{l}\text { Standard } \\
\text { warna Nilai } \\
\text { pengukuran } \\
\text { yaitu 0; 12,5; } \\
25 ; \\
50 ; 100 \mathrm{mg} / \mathrm{l}\end{array}$ & 1 buah & $\begin{array}{l}\text { Mengukur kandungan } \\
\text { nitrat air budidaya }\end{array}$ \\
\hline 3 & $\begin{array}{l}\text { Phosphat } \\
\text { test kit }\end{array}$ & $\begin{array}{l}\text { Standard warna } \\
\text { Nilai } \\
\text { pengukuran } \\
\text { yaitu 0,1; 0,25; } \\
0,5 ; \\
1,0 ; 2,0 \mathrm{mg} / \mathrm{l}\end{array}$ & 1 buah & $\begin{array}{l}\text { Mengukur kandungan } \\
\text { fosfat air budidaya }\end{array}$ \\
\hline 4 & $\begin{array}{l}\text { Kalium } \\
\text { test kit }\end{array}$ & $\begin{array}{l}\text { Standard warna } \\
\text { Kapasitas } \\
470 \mathrm{mg} / \mathrm{l}, \\
\text { ketelitian 10 10 }\end{array}$ & buah & $\begin{array}{l}\text { Mengukur kandungan } \\
\text { kalium air budidaya }\end{array}$ \\
\hline
\end{tabular}

Pengambilan data dilakukan pada seluruh tambak budidaya gracilaria sebanyak 33 tambak (lima tambak di kawasan Crocoh, lima tambak di kawasan Kali Domas dan 23 tambak di kawasan Teluk). Selanjutnya, pengamatan secara detail dilakukan pada sembilan tambak sampel. Penetapan titik sampel berdasarkan jarak dari laut dan kesediaan petambak. Tambak sampel yaitu tiga tambak di Kawasan A-Crocoh (Tambak 1, Tambak 4, Tambak 5), tiga tambak di Kawasan B-Kali Domas (Tambak 6, Tambak 8, Tambak 9) dan tiga tambak di Kawasan C-Teluk (Tambak 11, Tambak 19, Tambak 33). Pengamatan pemantauan pengaruh pemekaran dilakukan di Tambak 4 Kawasan Crocoh.

Frekuensi pengamatan parameter kualitas air berupa suhu, kecerahan, salinitas, $\mathrm{pH}$ dan ketinggian air kawasan $\mathrm{A}$ (Crocoh) berbeda dengan kawasan B dan $\mathrm{C}$ (Kali Domas dan Teluk). Kawasan Crocoh diamati setiap hari sedangkan kawasan Kali Domas dan Teluk hanya satu minggu sekali. Perbedaan tersebut karena aksesbilitas kawasan Kali Domas dan Teluk yang memiliki waktu tempuh lebih lama.

$$
\text { Selama praktik akhir, data }
$$
dikumpulkan melalui dua cara yaitu mengikuti kegiatan petambak dan melakukan pengumpulan data secara mandiri.

Cara kerja pengumpulan data melalui kegiatan mandiri tergantung dengan parameter yang diamati yaitu sebagai berikut:

- Petambak (pemilik dan pengelola) :

1) Mengidentifikasi nama pemilik dan pengelola setiap kawasan.

2) Mewawancarai setiap individu berdasarkan hasil identifikasi butir (a) untuk memperoleh aspek teknis dan non teknis budidaya.

- Tambak (jumlah, tata letak, luas) :

1) Jumlah kepemilikan diperoleh melalui wawancara.

2) Luas tambak:

a. Memilih tambak yang mudah dan bisa diukur langsung dimensinya.

b. Melakukan pengukuran luas pada tambak yang telah ditetapkan sebagaimana butir (a).

c. Hasil pengukuran tambak contoh, digunakan untuk dasar perhitungan tambak lain menggunakan google earth.

- Jenis dasar tambak : 
1) Mengambil tanah dari dasar tambak sedalam $10 \mathrm{~cm}$ menggunakan tangan.

2) Mengamati secara visual jenis substratnya.

- Aksesbilitas :

1) Menghitung jarak pusat desa ke lokasi praktik memakai google earth.

2) Mengamati jenis transportasi yang dapat mencapai lokasi.

- Keamanan dan tenaga kerja : Mengacu data Kecamatan Pontang dan monografi Desa Domas.

- Desain dan konstruksi tambakmeliputi pematang dan pintu air.

1) Pengukuran tinggi dan lebar dasar pematang dilakukan menggunakan dasar perhitungan phytagoras.

2) Pengukuran pintu air yang meliputi panjang pintu air, lebar pintu air, serta kedalaman pintu air diukur secara langsung.

- Padat tebar gracilaria :

1) Memasang kuadran $5 \mathrm{~m} \times 5 \mathrm{~m}$ pada titik pengamatan seperti Gambar 3.

2) Mengambil dan menimbang gracilaria yang ada pada kuadran.

3) Mengembalikan gracilaria ke dalam kuadran.

Bobot gracilaria :

1) Membuat kerangka sampling dengan ukuran $25 \mathrm{~cm} \times 25 \mathrm{~cm}$ dan tinggi

1) $40 \mathrm{~cm}$ seperti pada Gambar 4 .

2) Meletakkan 100 gram rumput laut ke dalam kerangka tersebut.

3) Selama pengamatan, memberi perlakuan sesuai dengan perlakuan pada gracilaria lain dalam tambak.

4) Pemantauan pengaruh pemekaran dengan menggunakan kerangka sampling dengan frekuensi pemekaran yang berbeda (pemekaran setiap dua minggu, pemekaran setiap tiga minggu dan tanpa pemekaran) dengan tiga kali ulangan selama 45 hari.

\section{HASIL DAN PEMBAHASAN}

Penilaian aspek teknis berupa jenis dasar tambak dan sumber air. Seluruh kawasan memiliki jenis dasar tambak berlumpur. Faktor teknis yang perlu diperhatikan salah satunya adalah jenis dasar tambak. Semua dasar tambak berupa lumpur halus. Sedangkan, Indriani dan Sumarsih (2005) dan SNI 7578 : 2010 menyatakan bahwa dasar tambak sebaiknya lumpur berpasir. Kondisi dasar tambak yang berupa lumpur berisiko menyebabkan gracilaria terbenam ke dalam lumpur. Gracilaria yang terbenam di dalam lumpur tidak bisa melakukan fotosintesis dan penyerapan nutrien secara normal sehingga mengakibatkan kematian. Pernyataan tersebut serupa dengan Trono (1988) bahwa pada tambak dengan dasar berlumpur membuat gracilaria mudah terbenam dalam lumpur dan mati.

\section{Perencanaan (Planing)}

Perencanaan sumberdaya manusia terkait pengorganisasian dilakukan secara sederhana. Sumberdaya manusia terdiri dari pemilik, pengelola, pemanen bandeng, pemanen gracilaria, bagian transportasi dan bagian melumpur. Sumberdaya bagian pengelola tambak ditunjuk melalui pengajuan diri secara lisan oleh calon pengelola tanpa seleksi dan kriteria khusus. Sedangkan penunjukan bagian panen dan transportasi hasil panen dilakukan sehari sebelum pelaksanaan. Perencanaan tersebut tidak dilaksanakan secara tertulis sehingga berisiko pada penerapan perencanaan.

Perencanaan teknis terkait dengan faktor produksi yang dikelola selama budidaya. Sedangkan, pembelian alat dilakukan dengan memperkirakan jumlah kebutuhan menurut pengalaman. Perencanaan manajemen dan teknis yang dilakukan akan berpengaruh langsung pada finansial. Perencanaan faktor keuangan disesuaikan dengan kondisi keuangan pemilik. Pemilik yang memiliki beberapa pengelola, tidak memisahkan keuangan per pengelola dan masih digabungkan dengan uang pribadi. Perencanaan tidak dilakukan pada sumber dana, alokasi, penyusutan, perhitungan kebutuhan yang akan dikeluarkan sehingga berisiko terhadap ketersediaan dana selama proses budidaya, menghambat pemenuhan kebutuhan budidaya dan merugikan pemilik karena penyusutan tidak dihitung sebagai biaya tetap yang harus dihitung pada saat pembagian keuntungan. Perencanaan hanya pada pembagian keuntungan dengan rincian untuk pengelola $20-33 \%$ dari laba bersih, pemilik sebesar $80-67 \%$ dari laba bersih, pemanen bandeng $R p$ $1.000 / \mathrm{kg}$ - Rp $1.500 / \mathrm{kg}$, pemanen gracilaria Rp $1.200 / \mathrm{kg}-\mathrm{Rp} 1.500 / \mathrm{kg}$ dan transportasi bandeng maupun gracilaria sebesar $\mathrm{Rp}$ 150/kg - Rp 500/kg. 


\section{Produksi}

Pelaksanaan tugas yang dilakukan masih belum maksimal. Sebanyak 24\% pemilik tidak pernah berkunjung ke tambak, $15 \%$ berkunjung setiap siklus, $15 \%$ berkunjung setiap minggu dan $46 \%$ berkunjung setiap hari. Pemberian instruksi oleh pemilik kepada pengelola yang dilakukan secara langsung sebesar $79 \%$, melalui alat komunikasi $12 \%$ dan melalui orang lain $9 \%$. Banyak dari pengelola yang masih membutuhkan arahan karena kompetensi yang dimiliki terbatas sebanyak $73 \%$ pengelola belum pernah mengikuti seminar atau pelatihan terkait budidaya gracilaria. Akibat dari sedikitnya kunjungan dan instruksi yang tidak diberikan secara langsung, terjadi jarak pengetahuan yang berdampak pada budidaya yang tidak tertangani secara maksimal.

Pelaksanaan dari segi biaya belum maksimal. Pada pelaksanaannya, 94\% petambak menggunakan dana yang bersumber dari keuangan pribadi dan 6\% pinjaman. Namun, dokumentasi biaya tersebut tidak lengkap dan tidak disimpan. Selain itu, kebutuhan tidak terpenuhi secara keseluruhan karena tidak ada perencanaan alokasi keuangan dan sumber dana. Dokumentasi yang tidak lengkap menyebabkan kesulitan menghitung hasil produksi, baik produksi pada siklus tersebut maupun siklus yang sudah terlewati. Penghitungan hasil produksi selama beberapa siklus, dapat bermanfaat untuk melihat tren peningkatan dan penurunan produksi secara valid. Tanpa adanya rekaman tersebut, maka sulit untuk melakukan perbaikan dan pengembangan usaha.

\section{Penanaman}

Cara penanaman dilakukan dengan menebarkan gracilaria ke seluruh area tambak. Satu karung dapat dibagi menjadi tiga rumpun besar dengan jarak 2,5 $\mathrm{m} /$ titik (menyesuaikan luasan wadah dan jumlah karung rumput laut). Selanjutnya, menebarkan rumpun ke sekeliling letak rumpun sebanyak 300 gram/genggam. Bobot tebar tersebut berbeda dengan Anggadiredja $d k k$.(2006) yang menyarankan bobot sekitar $100 \mathrm{gram} /$ rumpun.

Jumlah bibit yang ditebarkan pada awal penebaran bervariasi. Selain bobot bibit awal, kepadatan gracilaria diukur per $\mathrm{m}^{2}$ pada awal budidaya. Hasil pengukuran dirinci pada Tabel 2. Bibit yang disisakan di Tambak $1\left(100 \mathrm{gram} / \mathrm{m}^{2}\right)$ sesuai SNI 7578 : 2010 yaitu sebanyak 1-2 ton/ha. Bibit di Tambak 33 (57 gram) terlalu sedikit sedangkan bibit di tambak lain terlalu banyak. Tambak yang terlalu padat menyebabkan persaingan nutrisi tinggi sehingga pemenuhan kebutuhan unsurunsur yang diperlukan untuk pertumbuhan menjadi terbatas. Keterbatasan pemenuhan unsur yang dibutuhkan menyebabkan pertumbuhan gracilaria tidak maksimal. Jumlah tersebut belum sesuai dengan Anggadiredja dkk. (2006) dan Prabowo dan Farchan (2008) bahwa pada awal budidaya penebaran gracilaria adalah 1-1,5 ton atau setara sekitar $100 \mathrm{gram} / \mathrm{m}^{2}$.

Tabel 2. Jumlah bibit

\begin{tabular}{|l|l|c|}
\hline No & \multicolumn{1}{|c|}{ Lokasi } & Bobot bibit $\left.\mathbf{( g r a m} / \mathbf{m}^{\mathbf{2}}\right)$ \\
\hline 1 & Tambak 1 & 100 \\
\hline 2 & Tambak 4 & 501 \\
\hline 3 & Tambak 5 & 471 \\
\hline 4 & Tambak 6 & 627 \\
\hline 5 & Tambak 7 & 773 \\
\hline 6 & Tambak 9 & 429 \\
\hline 7 & Tambak 11 & 831 \\
\hline 8 & Tambak 19 & 604 \\
\hline 9 & Tambak 33 & 57 \\
\hline
\end{tabular}

\section{Pengamatan Pertumbuhan}

Hasil pengukuran bobot selama praktik dapat dilihat pada Gambar 1 Hasil pengukuran tidak dapat dibandingkan dengan target karena penetapan target pertumbuhan tidak dilakukan pada saat perencanaan. Hasil pengukuran bobot 
dibandingkan dengan pendapat Prabowo dan Farchan (2008) bahwa pertumbuhan yang dianggap menguntungkan adalah di atas $3 \%$.

Gambar 1a menunjukkan pertumbuhan yang berbeda pada Tambak 1 dan 5. Pada dua minggu pertama budidaya, Tambak 5 mengalami pertumbuhan yang lebih pesat dari pada Tambak 1. Tambak 1 memiliki pertumbuhan yang lambat pada 2 minggu pertama namun meningkat secara konsisten pada minggu selanjutnya. Laju pertumbuhan rata-rata $1,95 \%$. Pertumbuhan di atas $3 \%$ hanya terjadi pada minggu ke 3 dan 4 di Tambak 1 dan minggu pertama di Tambak 5.

Penurunan laju pertumbuhan pada Tambak 5 terjadi karena pengaruh tinggi air, salinitas dan kadar kalium. Pada 2 minggu pertama salinitas Tambak 5 22-24 g/l yang mendekati nilai optimum 15-20 g/l (Chen,
1976 dalam Sjafrie,1990) sedangkan selanjutnya 22-30 g/l. Kalium dibutuhkan dalam jumlah yang banyak untuk asimilasi energi yang dihasilkan proses fotosintesis oleh sel tanaman sesuai dengan pendapat Setiadji dkk. (2012). Air yang rendah membuat penetrasi cahaya dapat masuk hingga dasar perairan sehingga fotosintesis berjalan maksimal. Adapun minggu selanjutnya, ketinggian air bertambah $4 \mathrm{~cm}$ sedangkan pertumbuhan meningkat pesat sehingga sebagian thallus terlalu dekat permukaan. Thallus yang terlalu dekat permukaan, terpapar suhu yang terlalu tinggi dalam waktu yang cukup lama. Kondisi yang tidak menguntungkan bagi gracilaria menyebabkan thallus layu dan mati. Laju pertumbuhan paling rendah terjadi pada minggu keempat dengan nilai laju pertumbuhan bernilai negatif.

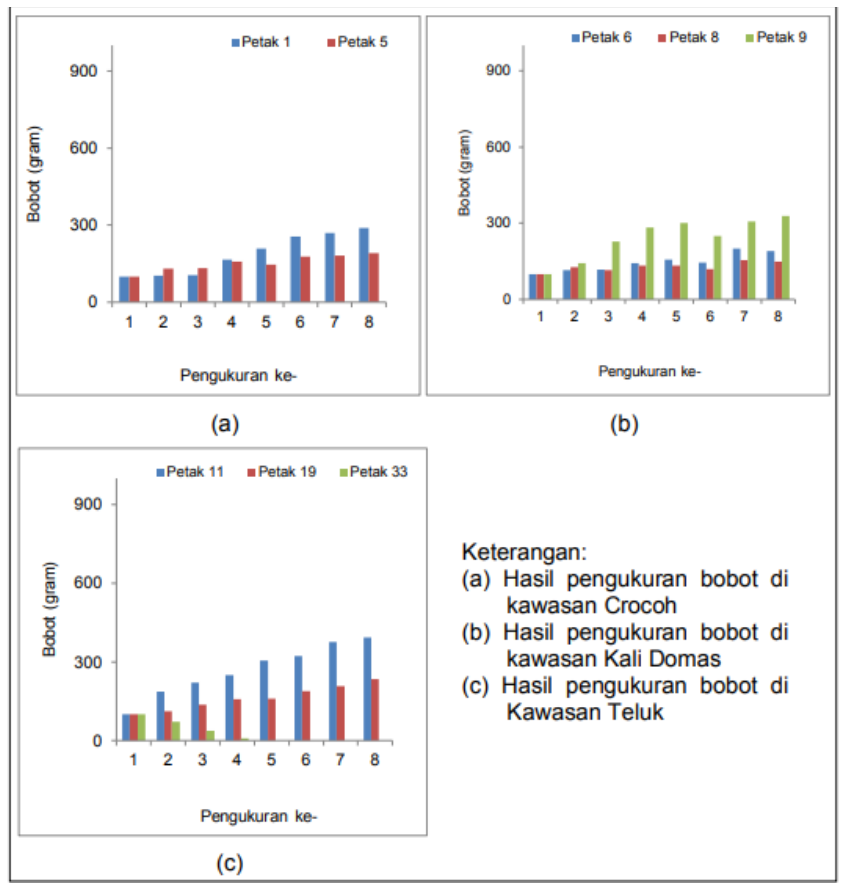

Gambar 1. Hasil pengukuran bobot tanpa pemekaran

Peningkatan pertumbuhan Tambak 1 terjadi karena parameter semakin memenuhi kebutuhan gracilaria. Pada minggu ketiga dan seterusnya, kandungan nitrat meningkat. Nitrat adalah komponen utama nutrisi untuk pertumbuhan, sehingga suplai yang tersedia berpengaruh pada pertumbuhan. Selain itu, ketinggian air yang berada pada kisaran 50 $\mathrm{cm}$ menjadi ideal ketika gracilaria mulai tumbuh. Ketinggian air pemeliharaan tidak sesuai SNI 7578 : 2010 yang menyatakan bahwa ketinggian air selama pemeliharaan antara $50-70 \mathrm{~cm}$.
Gambar 1b menunjukan pertumbuhan terbaik pada kawasan ini adalah Tambak 9 sedangkan pertumbuhan paling lambat adalah Tambak 8 dengan ratarata laju pertumbuhan 1,53\%. Tambak 8 cenderung memiliki nilai nitrat yang lebih rendah dibandingkan tambak sampel lain. Selain itu, ketinggian air Tambak 8 lebih tinggi dibandingkan tambak lain pada kawasan yang sama. Sedangkan Tambak 9 memiliki kadar nitrat yang lebih tinggi sehingga kebutuhan gracilaria lebih terpenuhi dibandingkan Tambak 8. Pertumbuhan Tambak 6 memiliki nilai rata- 
rata 1,2 gram $/$ hari. Tambak 6 mengalami kekeringan pada minggu pertama (tinggi air 9 $\mathrm{cm}$ ) dan minggu keempat (tinggi air $12 \mathrm{~cm}$ ). Kekeringan disebabkan kebocoran pintu air sehingga tidak mampu menahan air, tidak adanya air pasang dan adanya evaporasi. Tenaga panen saat kekeringan terlalu sedikit sehingga banyak gracilaria yang tidak terpanen dan mengalami kematian. Kematian tersebut meningkatkan kadar nitrat hingga mencapai $50 \mathrm{mg} / \mathrm{l}$. Hal tersebut berdampak pada laju pertumbuhan yang menurun pada minggu tersebut. Pertumbuhan pada Tambak 6 tidak sesuai dengan Prabowo dan Farchan (2008) yang menyatakan pertumbuhan yang menguntungkan adalah di atas 3\%.

Gambar 1c memiliki perbedaan pertumbuhan. Laju pertumbuhan Tambak 11, Tambak 19 dan Tambak 33 berturutturut $3 \%, 2,1 \%$ dan $-32 \%$. Perbedaan pertumbuhan tersebut disebabkan perbedaan parameter lingkungan. Fosfat, nitrat dan ketinggian air pada Tambak 11 dan Tambak 19 berbeda dengan nilai yang lebih tinggi pada Tambak 11. Ketersediaan nitrat dan fosfat membuat suplai nutrisi untuk pertumbuhan terpenuhi sehingga pertumbuhan menjadi lebih maksimal. Ketinggian air Tambak 11 lebih mendekati SNI 7578 : 2010 sebesar 50-70 cm. Sedangkan pada Tambak 33, terjadi penurunan bobot secara drastis karena salinitas perairan yang terus menurun hingga nilai $0 \mathrm{~g} / \mathrm{l}$. Penurunan bobot tersebut disebabkan habitat yang sudah tidak sesuai dengan kebutuhan gracilaria. Keadaan tersebut tidak sesuai dengan SNI 7578 : 2010 bahwa persyaratan lokasi bagi gracilaria salah satunya adalah salinitas 15 $30 \mathrm{~g} / \mathrm{l}$.

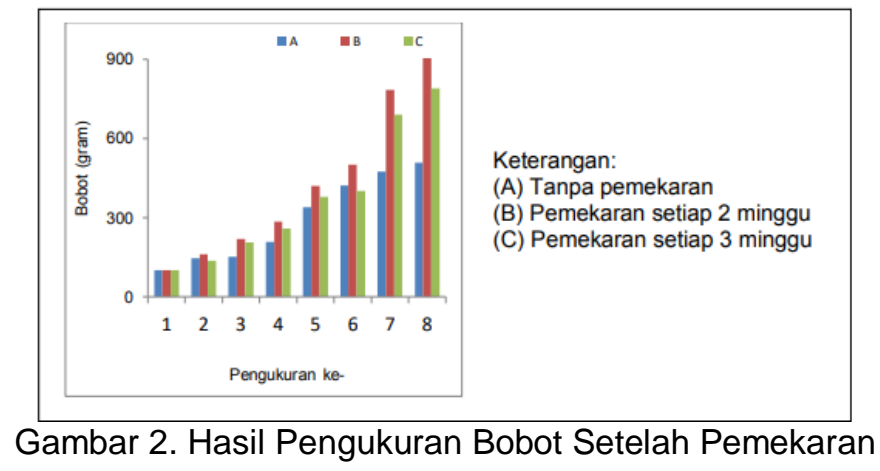

\begin{abstract}
Dari Gambar 2 dapat ditarik kesimpulan bahwa pemekaran mempengaruhi hasil pertumbuhan. Pemekaran setiap 2 minggu, memiliki hasil pertumbuhan terbaik dibandingkan pemekaran setiap 3 minggu dan tanpa pemekaran. Pemekaran setiap 2 minggu membuat kepadatan gracilaria di dalam tambak lebih merata dibandingkan pemekaran setiap 3 minggu dan tanpa pemekaran sehingga penyerapan nutrisi dapat berjalan lebih efektif. Hasil pengukuran bobot akhir perlakuan tanpa pemekaran, pemekaran setiap 3 minggu dan pemekaran setiap 2 minggu berturut-turut menjadi 5 kali lipat, 8 kali lipat, dan 9 kali lipat dibandingkan dengan bobot awal.
\end{abstract}

Pemekaran

memberikan keuntungan. Pemekaran yang dilakukan meningkatkan produktifitas lahan hingga $80 \%$ sehingga kuantitas panen meningkat. Rata-rata laju pertumbuhan gracilaria yang dipekarkan memenuhi standard yaitu di atas 3\%. Hal tersebut sesuai pendapat Prabowo dan Farchan (2008) bahwa pertumbuhan yang dianggap menguntungkan adalah di atas $3 \%$.

\section{Panen}

Panen yang dilakukan tanpa memilih thallus muda atau tua. Thallus bibit yang digunakan beragam umurnya. Sementara seharusnya thallus muda yang menjadi bibit sesuai dengan Anggadiredja dkk. (2006) bahwa thallus muda dipetik untuk dijadikan bibit dan dipisahkan dengan thallus tua yang dijemur. Hasil panen berkisar $700-9.000 \mathrm{~kg}$ sekali panen. Panen belum sepenuhnya maksimal yan dapat dilihat pada Tabel 3. Hal tersebut dikarenakan banyak gracilaria yang terkena lumut sutera sehingga tidak bisa dipanen. Selain itu hasil panen yang diambil tidak keseluruhan, melainkan menyisakan bagianuntuk bibit. Efek dari hal tersebut, bagian untuk bibit bahkan cenderung lebih banyak dari hasil panen. Hal tersebut tidak sesuai SNI 7578 : 2010 ya ng menyatakan hasil gracilaria $10-15$ ton basah/ha/6 bulan. 
Tabel 3. Perbandingan bibit dan hasil produksi

\begin{tabular}{|c|c|c|c|c|c|c|}
\hline \multirow{2}{*}{$\begin{array}{c}\text { No } \\
\text { Tambak }\end{array}$} & \multirow{2}{*}{$\begin{array}{l}\text { Bibit } \\
\left(g / m^{2}\right)\end{array}$} & \multirow{2}{*}{$\begin{array}{l}\text { Luas } \\
\text { (ha) }\end{array}$} & \multirow{2}{*}{$\begin{array}{l}\text { Total bibit } \\
(\mathbf{k g})\end{array}$} & \multicolumn{2}{|c|}{ Total Panen (kg) } & \multirow{2}{*}{$\begin{array}{c}\text { Produktivitas } \\
\left(\mathrm{g} / \mathrm{m}^{2}\right)\end{array}$} \\
\hline & & & & Basah & Kering & \\
\hline 1 & 100 & 4 & 4.000 & 18.000 & 3.000 & 75 \\
\hline 4 & 501 & 5 & 25.050 & 25.800 & 4.300 & 86 \\
\hline 5 & 471 & 8 & 37.680 & 5.000 & 2.500 & 31 \\
\hline 6 & 627 & 3 & 18.820 & 14.160 & 2.360 & 79 \\
\hline 8 & 773 & 4 & 30.920 & 24.000 & 4.000 & 100 \\
\hline 9 & 429 & 4 & 17.147 & 30.000 & 5.000 & 125 \\
\hline 11 & 831 & 9 & 74.790 & 17.400 & 2.900 & 32 \\
\hline 19 & 604 & 6 & 36.240 & 27.600 & 4.600 & 77 \\
\hline 33 & 57 & 4 & 2.280 & 15.000 & 2.500 & 63 \\
\hline
\end{tabular}

Salah satu langkah untuk menjaga mutu hasil panen adalah melalui penggunaan waring. Penerapan penggunaan waring dilakukan oleh $33 \%$ pembudidaya, sedangkan $67 \%$ lainnya tidak menggunakan. Kapasitas waring $100 \mathrm{~m}$ adalah $100 \mathrm{~kg}$ kering sehingga apabila panen pada hari tersebut $>100 \mathrm{~kg}$ kering, $33 \%$ pembudidaya tersebut menjemur tanpa alas. Hasil panen dengan penjemuran menggunakan waring memiliki tingkat kebersihan yang lebih baik karena unsur pengotor seperti tanah dan serpihan daun lebih sedikit. Perbandingan bobot basah : kering adalah $1: 6$.

\section{Pasca panen}

Kegiatan pasca panen dilakukan Kelompok Subur Makmur Pontang dengan kegiatan seperti pada Gambar 27. Pada penimbangan di pengepul, dilakukan pemotongan bobot penimbangan. Bobot rata-rata setiap karung adalah $25 \mathrm{~kg}$. Potongan $1 \mathrm{~kg} / \mathrm{karung}$ untuk kondisi hasil panen yang lembab dengan perkiraan kandungan air 20\%. Potongan $2-3 \mathrm{~kg} / \mathrm{karung}$ untuk kondisi hasil panen yang dianggap banyak benda asing (kotor). Potongan harga hingga $45 \%$ berlaku untuk hasil panen yang terkena hujan sehingga warna sudah berubah. Gracilaria yang telah sampai di gudang, dilakukan penjemuran ulang. Tujuan penjemuran ulang untuk mengetahui kualitas gracilaria dan memastikan tidak dilakukan pengoplosan dengan kualitas yang lebih rendah. Daya tampung gudang mencapai 80 ton. Penjemuran dalam sehari pada cuaca panas hingga 3-4 kali penjemuran yang dilanjutan penimbangan.Pengemasan dilakukan pada hari yang sama, tepat setelah penjemuran dan pengepresan.

Pengemasan menggunakan karung goni dengan ukuran $75 \times 75 \times 150 \mathrm{~cm}$. Pelabelan menggunakan spidol dengan menuliskan kode lokasidan grade konten.

\section{Finansial}

Komponen analisa terdiri dari biaya investasi, biaya tetap, biaya tidak tetap dan pendapatan. Biaya investasi meliputi pengeluaran untuk membeli lahan, membuat rumah jaga, pintu air, bibit gracilaria, alat panen, alat pengeruk lumpur, plastik dan terpal, waring, perahu, dan saringan pada pintu air (ram). Biaya tetap meliputi penyusutan, sewa lahan dan biaya pembuangan lumpur. Biaya tidak tetap meliputi pengeluaran untuk bibit bandeng, pupuk, saponin, upah pengelola, upah jaring, upah panen dan upah tanspotasi. Pendapatan bersumber dari hasil panen gracilaria dan hasil panen bandeng.

Biaya investasi tertinggi yaitu sebesar Rp 4.077.580.000,- (Tambak 11), terendah sebesar Rp 12.300.000,- (Tambak 18), dengan rata-rata $\mathrm{Rp}$ 1.827.049.545,-. Biaya tetap tertinggi sebesar Rp 128.521.333,- (Tambak 19), terendah sebesar Rp 1.794.286,- (Tambak 27) dengan rata-rata $\mathrm{Rp} 17.468 .739,-$. Biaya tidak tetap paling tinggi yaitu sebesar Rp 104.422.500,(Tambak 4), terendah yaitu sebesar $R p$ 12.647.000,- (Tambak 12), dengan rata-rata Rp 45.632.919,-.

\section{Laba Rugi}

Keuntungan yang diperoleh berbeda setiap tambaknya. Rata-rata laba sebesar Rp 34.100.258,-. Keuntungan tertinggi diperoleh Tambak 4 dengan laba Rp 
116.898.952,--. Terdapat empat tambak yang mengalami kerugian dari keseluruhan 33 tambak. Kerugian terbanyak adalah Tambak 20 dengan kerugian $\mathrm{Rp}$ 93.085.333,-Kerugian budidaya terjadi akibat biaya sewa lahan (biaya tetap) yang tinggi namun tidak tertutupi oleh hasil produksi yang belum maksimal.

\section{B/C Ratio}

Nilai B/C Ratio yang diperoleh berbeda setiap tambaknya. Rata-rata nilai $B / C$ ratio yaitu 1,65 . Nilai tertinggi yaitu Tambak 6 dengan nilai 2,62. Hal ini berarti setiap 1 rupiah yang diinvestasikan akan menghasilkan 2,62 rupiah. Sedangkan tambak yang memiliki nilai paling rendah adalah Tambak 19 dengan nilai 0,65. Hal ini berarti setiap 1 rupiah yang diinvestasikan hanya akan menghasilkan 0,65 rupiah. Apabila nilai $\mathrm{B} / \mathrm{C}$ ratio kurang dari 1 , maka usaha mengalami kerugian. Penyebab kerugian adalah pendapatan lebih rendah dari biaya yang dikeluarkan.

\section{Break Even Point}

BEP yang diperoleh berbeda setiap tambaknya. BEP tertinggi adalah Tambak 14 dengan nilai BEP $181.127 \mathrm{~kg}$ atau $\mathrm{Rp}$ 1.014.311.586,-. BEP terendah adalah Tambak 27 dengan nilai $862 \mathrm{~kg}$ atau $\mathrm{Rp}$ 4.829.250,-. Rata-rata BEP adalah $16.828 \mathrm{~kg}$ atau $\mathrm{Rp}$ 94.235.182,-. Hal tersebut berarti usaha mengalami titik impas rata-rata saat menghasilkan $16.828 \mathrm{~kg}$ atau memperoleh pendapatan sebesar $R p$ 94.235.182,-. Perbedaan tersebut karena pada Tambak 14, laba diperoleh dari bandeng sebesar $51 \%$ sedangkan pada Tambak 27 sebesar 27\%. Bandeng merupakan komoditas polikultur yang ada pada budidaya gracilaria, namun untuk hasil panen tidak diperhitungkan petani karena dianggap hasil sampingan yang berfungsi untuk mendukung budidaya utama yaitu gracilaria.

\section{Payback Period}

PP yang diperoleh berbeda setiap tambaknya. Rata-rata PP yaitu 55,5 tahun. Hal tersebut berarti waktu yang dibutuhkan untuk pengembalian investasi yaitu selama 55 tahun 6 bulan. PP terlama yaitu Tambak 25 dengan lama PP 188,6 tahun. PP tercepat adalah Tambak 28 yaitu 0,3 tahun. Perbedaan tersebut disebabkan perbedaan investasi. Tambak 25 memiliki investasi sebesar Rp3.032.810.00 (status tambak milik sendiri) sedangkan Tambak 28 sebesar Rp15.880.000 (status tambak sewa).

\section{Return on Investmen}

$\mathrm{ROI}$ yang diperoleh berbeda setiap tambaknya. Rata-rata ROI sebesar $5,3 \%$. Hal ini berarti tingkat pengembalian modal produksi (meliputi biaya investasi dan biaya operasional) adalah 5,3\%. ROI tertinggi yaitu Tambak 28 sebesar 50,6\%. Sedangkan ROI terendah adalah Tambak 17 yaitu 0,5\%. Perbedaan tersebut disebabkan nilai modal produksi dan laba yang diperoleh berbeda sehingga mempengaruhi nilai tingkat pengembalian modal. Nilai modal produksi Tambak 28 yaitu Rp 109.882.619,- dengan laba Rp 55.597.381,-. Nilai modal produksi Tambak 17 yaitu Rp 30.124.743,- dengan laba $\operatorname{Rp} 25.710 .633,-$.

\section{KESIMPULAN}

Adapun kesimpulan dari penelitian ini adalah : Dari Segi Teknik : (1) Lokasi Tambak mulai petak 19 hingga Tambak 33 berjarak lebih dari $1 \mathrm{~km}$ dari sumber air laut sehingga sulit mendapatkan penyediaan air laut, (2) Pelaksanaan teknis terkait persiapan wadah, penanaman bibit, pengelolaan kualitas air, pengendalian hama dan penyakit serta penjemuran hasil panen kurang dilaksanakan dengan baik sehingga menghasilkan pertumbuhan gracilaria yang rendah (di bawah 3\%) dan hasil panen yang tidak maksimal. Dari segi manajemen : (1) Perencanaan belum dilakukan dengan baik karena tidak ada target produksi, tidak tertulis dan tidak terjadwal, (2) Pengorganisasian dilakukan tetapi tanpa acuan standard operasional prosedur sehingga pada pelaksanaan kurang maksimum, (3) Pelaksanaan kegiatan budidaya belum didasarkan pada suatu perencanaan yang tertulis dan terstruktur baik terkait target produksi maupun kegiatan ikutan budidaya lainnya untuk mencapai target produksi, (5) Pengendalian dan evaluasi belum dijalankan di seluruh tahapan kegiatan budidaya. Dari segi finansial : (1) Secara umum, budidaya gracilaria menguntungkan namun tidak terlalu tinggi yaitu rata-rata laba 29 tambak sebesar Rp 34.100.258,- (2\% dari rata-rata investasi) dengan empat tambak mengalami rugi, $\mathrm{B} / \mathrm{C}$ Ratio 1,65 , BEP unit $16.828 \mathrm{~kg}$ dengan BEP rupiah $\mathrm{Rp}$ 94.235.182,-; Payback periode 55 tahun 6 bulan dan ROI 5,3\%. 
Berdasarkan hasil penelitian adapun saran berdasarkan pelaksanaan penelitian yang sudah dilakukan yaitu dari segi teknik : (1) Melakukan aplikasi teknologi untuk mengurangi parameter lokasi yang tidak sesuai. Contohnya menggunakan sistem pemasukan air yang tidak mengaduk dasar karena dasar tambak berlumpur dan menggunakan pompa untuk membantu pemenuhan suplai air. Selain itu dapat mengalihkan pemanfaatan lahan untuk komoditas lain yang lebih sesuai dengan keadaan lokasi. (2) Melakukan pelaksanaan teknis berupa : (a) Mengolah lahan dan memberi saponin sebelum budidaya untuk meminimalisir adanya predator bandeng selama budidaya. (b) Melaksanakan pembibitan sesuai $\mathrm{SNI}$ yaitu 1-2 ton/ha. (c) Merangsang laju pertumbuhan dengan melakukan pemekaran dan pemberian pupuk. (d) Mengendalikan hama dan penyakit melalui pengelolaan lahan dan monitoring kualitas air secara berkala. (e) Menjemur hasil panen menggunakan waring. Dari segi manajemen : (1) Sebaiknya melakukan perencanaan yang tetulis, tejadwal dan menentukan target produksi. (2) Melakukan pengorganisasian dengan acuan standard operasional prosedur sehingga pada pelaksanaan bisa maksimum..(3) Melaksanakan kegiatan budidaya berdasarkan suatu perencanaan yang tertulis dan terstruktur baik terkait target produksi maupun kegiatan ikutan budidaya lainnya untuk mencapai target produksi. (4) Menjalankan pengendalian dan evaluasi di seluruh tahapan kegiatan budidaya. Dari segi finansial : (1) Sebaiknya meningkatkan kegiatan manajemen dan teknis sehingga pendapatan bisa lebih maksimal.

\section{DAFTAR RUJUKAN}

Anggadireja, J.T., A. Zatnika, H. Purwoto, dan S. Istini. 2006. Rumput

Laut.Penebar Swadaya. Jakarta. iv + 148 hal.

Indriani, H. dan E. Sumiarsih. 2005. Budi Daya, Pengolahan, dan Pemasaran Rumput Laut. Penebar Swadaya. Depok. vii + 99 hal.

Jagadeesan, L., A. Kannadasan, P. Anantharaman, P. Perumal dan M. Thangaraj.
2010. "Assesment of Amonium Uptake by Marine Macroalga". Current

Research Journal of Biological Science. Vol 2. Hal 150-153.

Jamal, E. 2016. "Aspek Ekonomi Pengembangn Usaha Budidaya Rumput Laut di Indonesia". Forum Penelitian Agro Ekonomi. Vol.9. Hal 19-21.

Parker, R. 2012. Aquaculture Science. Third Edition. New York : Delmar. xiv +652 p.

Prabowo, G. dan M. Farchan. 2008. Teknik Budidaya Rumput Laut. BAPPL STP Serang. Serang. vii + 95 hal.

Primyastanto, M. 2011. Feasability Study Usaha Perikanan. Universitas Brawijaya

Press. Malang. $x v i+218$ hal.

Rahmantya, K.F., A.D. Asianto, D. Wibowo, T. Wahyuni dan W.A. Somad. 2015a.

Analisis Data Pokok Kementerian Kelautan dan Perikanan 2015. Pusat Data Statistik dan Informasi. Jakarta. xvi +170 hal. 2015b. Kelautan dan Perikanan dalam Angka Tahun 2015. Pusat Data

Statistik dan Informasi. Jakarta. xxviii +308 hal.

Rahmaningsih, S. 2012. "Penerapan Teknologi Penggunaan Rumput Laut sebagai

Biofilter Alami Air Tambak untuk Mengurangi Tingkat Serangan Penyakit pada Udang Vannamei (Litopenaeus vannamei)". Jurnal Teknologi

Perikanan dan Kelautan. Vol 2. No 2. Hal 11-16.

Setiaji, K., G.W. Santosa dan Sunaryo. 2012. "Pengaruh Penambahan NPK dan Urea pada Media Air Pemeliharaan terhadap Pertumbuhan Rumput Laut". Journal of marine Research. Vol 1. No 2. Hal 45-50.

Sunaryat, H.W. dan Istiqomah. 2008. Teknologi Budidaya Rumput Laut (Kappaphucus alvarezi). Balai Besar Pengembangan Budidaya Laut Lampung. Lampung. Hal 7-10.

Yulianto, B., R. Ario dan A. Triono. 2006. "Daya Serap Rumput Laut (Gracilaria sp.) terhadap Logam Berat Tembaga (Cu) sebagai Biofilter". IImu Kelautan. Vol 11. No 2. Hal 72-7 